\title{
A Moral World without God-On the Religion of Humanity of George Eliot in Silas Marner
}

\author{
Liang Zhang \\ Teachers' College of Beijing Union University, No.5 Wai Guan Xie Jie Street, Beijing 100011, China \\ Lingqin Zeng \\ Teachers' College of Beijing Union University, No.5 Wai Guan Xie Jie Street, Beijing 100011, China
}

\begin{abstract}
Among the Victorian writers, George Eliot deserves to be a unique one. Her male pseudonym, the impugnation of Christianity as well as her nonconformist marriage achieve this stellar female novelist in British literature. Ironically, Eliot was exactly famous for describing social religion and morality of the day. Eliot's attitude toward Christianity is dichotomous: though deeply influenced by Christianity, she is full of suspicion of it; she doesn't believe in the Christian God but keeps on spreading the religious and moral codes in her works; she can't totally accept Christian belief, meanwhile she is unable to get rid of sympathy and understanding towards various religious feelings. Impugnation of Christianity and the dependence on Christianity coexist in her spiritual world. She is a skeptic of religion but by no means non-atheist. Eliot establishes a religious world of her own, a world without belief in God but in Man, that is, religion of humanity. Reviewing the forming background of Eliot's religion of humanity as well as a close textual reading of Silas Marner, the article tentatively concludes the connotation as well as essence of Eliot's religion of humanity and maintains that religion of humanity, in essence, is one of the ways in which Victorians like George Eliot come to remedy the loss of conventional religious faith; it exists as an innovation of Christianity, transferring the focus from divinity to secularity, from God to Man. Furthermore, the paper points out the realistic significance of examining Eliot's religion of humanity in the material-oriented modern society.
\end{abstract}

Index Terms - religion of humanity, christianity, moral values, redemption

\section{INTRODUCTION}

Among the extraordinary English novelists who wrote during the eighteenth and nineteenth centuries, George Eliot deserved to be a unique one. George Eliot is renowned for being the "voice of a century", the spirit and the mind of the nineteenth century. However, she was such a controversial character that since her first appearance in English literature circle, praise and blame, exaltation together with slander never left her. Too much ambiguity in her life and her works knitted for her a mystic veil. Even now, critics regard her as an enigma. Maybe that's the exact reason why literary critics never lose their interest in George Eliot until today.

George Eliot was the pseudonym of Mary Ann Evans. Though coming from a comparatively humble family, she received a perfect education endowed by her benign and wise father. Besides her fame as novelist, she was also known as a successful translator, critic, essayist and moralist.

Though starting literary creation rather late, almost in her thirties, George Eliot was a prolific writer. Eliot began her work with the arduous translation of Strauss's Life of Jesus, Spinoza's Ethics, and Ludwig Feuerbach's The Essence of Christianity. The three translations not only started her artistic life, but also laid the theological and ideological foundation in her real life and works.

Anthony Trollope (1923)admitted in his autobiography, "at the present moment George Eliot is the first of English Novelists". David Cecil, the famous literary historian, declared her as "the only novelist of her time" (Handley, 1990). Henry James, one of the most influential American novelists and literary critics, showed due respect for her, speaking of her novel as "not primarily a picture of life, capable of deriving a high value from its form, but a moralized fable, the last word of a philosophy endeavoring to teach by example" (Handley, 1990). Leslie Stephen, whose authoritative voice was much looked up to in both American and Europe, defined her position in Victorian literature this way, "the works of George Eliot may thereafter appear as marking the termination of the great period English fiction which began with Scott. She may hereafter be regarded as the last great sovereign of a literary dynasty" (Haight, 1965). Leslie's daughter, Virginia Woolf, the great woman writer, highly valued Eliot's artistic talent and profound insight. In her lecture adapted from "Celebration of Women Writers", which was firstly published in The Times Literary Supplement on November $20^{\text {th }}$, 1919, Woolf, talking of Eliot's works, said “That greatness is here we can have no doubt. The width of the prospect, the large strong outlines of the principal features, the ruddy light of her early books, the searching power and reflective richness of the later tempt us to linger and expatiate beyond our limits"(Stonyk, 1983). Tracing back the whole life of George Eliot, Woolf praised her as the pride and paragon of all her sex.

However, George Eliot's reputation has gone through ups and downs. Her high standing as a novelist actually 
declined towards the end of her life. George Eliot restored her fame since 1919, especially through the recommendation of Virginia Woolf. At the end of Second World War, F. R. Leavis published articles about George Eliot in Scrutiny, which later formed part of The Great Tradition. Leavis followed the lead of Virginal Woolf in trying to include George Eliot as one of the few great writers. Leavis(1995) held in The Great Tradition, "the Great George Eliot is the novelist of reminiscence; George Eliot who writes out of her memories of childhood and youth, renders the poignancy and charm of personal experience, and gives us, in a mellow light, the England of her young days, and of her days then still alive in family tradition". For Leavis, the most fitting adjective to describe Eliot was the charismatic "Tolstoyan", "George Eliot, of course, is not as transcendently great as Tolstoy, but she is great, and great in the same way" (Carroll, 1966). From the late 1950s onwards, criticism of her novels in a variety of forms has proliferated. Once and for all, George Eliot's position in English literature is reestablished and consolidated. George Eliot has been a pet topic among critics, and various criticism methods are applied to Eliot study: historical, psychoanalytical, structural, feminist, deconstructive, comparative research, discourse-analytical, etc.

In "Articles on George Eliot in 2002: a Selective Survey", Professor Donald Hawes(2004) from University of Westminster made a summary of research on Eliot. He found that two important aspects of George Eliot's novels- her realism and her comedy - were the subjects of many essays. Peter Melville Logan(2002), in "George Eliot and the Fetish of Realism", stated that George Eliot was deeply interested in the influence of positivism and its associated fetishism"; Deanna Kreisel discussed the problems of George Eliot's authorial personality from various angles. Besides, the significance of music in George Eliot's life and work has been fruitfully explored by a number of scholars. Grace Kehler explored the complex and sometimes ambiguous relationships between musical performance, particularly singing and opera, and the human tensions in George Eliot's last novel. Doctor Donald held in the summary that comparison could be a rewarding critical approach in this period of study. Moreover, Donald indicated that George Eliot's poetry still remained a neglected area of her imaginative work, and any remarks on her poetry would be welcome (2004).

Compared with her contemporaries, Eliot hasn't received sufficient critical recognition she deserves in China. F. R. Leavis considered that among Britain novelists, except Jane Austin, George Eliot, Henry James and Conrad, no one else was worth reading. While in China, Jane Austin is obviously paid more attention than Eliot. Young students are very familiar with Austin's works such as Sense and Sensibility, Pride and Prejudice, Emma, etc. Dickens, the contemporary of Eliot, is far more popular in China. Fortunately, more and more attention is paid to this extraordinary Victorian writer. Articles and research on the great female writer begin to appear in recent years. Generally speaking, literary research on George Eliot in China falls into three categories: firstly, the research on George Eliot and interpretations of her novels; secondly, study of the factors that influenced George Eliot in her creation and the influence Eliot brought to other writers; lastly, various minor research methods. To sum up, literary criticism on George Eliot in China still has the following deficiencies: the critical angles are not complete; comparative study is less used in critics. Moreover, there is no monograph of George Eliot in China. These insufficiencies are exactly the directions for all the critics and zealous readers to follow in the future study on George Eliot.

Among various research angles, the fundamental and predominant concerning her life and works is her religious attitude. George Eliot endows each of her novels with inflexible and complex religious and moral ideas. George Eliot, deeply influenced by her families, is a pious Christian since her childhood to youth. What cause the young girl to question her religion in her twenties? How does she form religion of humanity? And what are the connotations of religion of humanity? In hope for solving these problems, the article, revovling around the formation and the essence of Eliot's religion of humanity, makes a tentative interpretation of Eliot's religion of humanity as well as the textual interpretation in Silas Marner.

Under the influence of personal experience, social movement and theory together with an extensive reading of various philosophic works, especially through her theological and literary translations, Eliot redefined the essence of religion and established a religious and moral world of her own, a moral world without belief in God but in human love. It is the essence of religion of humanity. Eliot's religion entailed two aspects: on one hand, Eliot absorbed the reasonable moral ideas in Christianity, such as philanthropy, submission, self-repression and so on; on the other hand, Eliot brought forth her own innovations as union of altruism and egoism, relativity of good and evil, and a new pattern of penance. The two aspects constituted the connotations of George Eliot's religion of humanity. Through the interpretation, it is quite clear that religion of humanity, in essence, is a kind of life attitude rather than a religion for its putting emphasis on "humanity" instead of "religion". George Eliot not only spread her ideas of religious belief and moral codes in her novels, but also earnestly practiced what she advocated in real life. Hence, George Eliot was not only regarded as a great novelist and moralist, but also the pride and paragon of the women.

\section{GEORgE Eliot'S RELIGION OF HuMANity: From Divine To HuMAN}

Dorothea in Middlemarch once said: "I have always been finding out my religion since I was a little girl" (Eliot, 1994). Literary critics have also been endeavoring to interpret George Eliot's religious view because it is the key to understand Eliot's works as well as her ideology. Generally speaking, there are two opposite views on George Eliot's religion. Some critics hold that Eliot is an atheist, a godless woman. At the end of Eliot's life, the reviewer W. H. Mallocb wrote of Eliot in The Edinburgh Review published in October 1879, "She is the first great Godless writer of 
fiction that has appeared in England [...] the first that has appeared in Europe"(Spiltters, 1993). This statement shocked many critics and readers in Victorian era; while other critics contend that Eliot is a non-atheist, which can be illustrated from her real life and novels. They hold that George Eliot defied the traditional Christianity, but she never completely deserted religion. According to the autobiography, Eliot went back to church at the last period of her life; besides, she married John Cross, a twenty years younger man. It is difficult for critics to thoroughly understand her motives. However, a formal letter from her brother Isaac broke his silence of twenty-five years. Isaac congratulated her on her marriage and claimed that this matter was Eliot's first respectability in his eyes, and that he was very happy for her finally getting married formally. Eliot's final marriage is extensively regarded as the compromise to the traditional religion and morality. Why is George Eliot's religious idea so complicated? What on earth is Eliot's belief in religion? How did she form such an ambivalent attitude towards religion? To solve these problems, the article necessarily begins with the formation of her religious ideas.

\section{A. Formation of George Eliot's Religious Ideas}

Like the majority of English people in the nineteenth century, George Eliot had a pious upbringing. Nevertheless, the $19^{\text {th }}$ century, also known as Victorian period, saw the various ideas appear frequently. In science and technology, the Victorians brought forth the modern idea of "invention", the notion that one could create solutions to problems, that man could create new means of bettering himself and his environment. In religion, the Victorians experienced a great age of doubt, and people began to raise doubts about institutional Christianity on a large scale. In ideology, politics, and society, Victorians created astonishing innovations and changes: democracy, feminism, unionization of workers, socialism, Marxism, and other modern movements took form.

The Victorian age was an age of paradox and power. The Catholicism of the Oxford Movement, Darwinism and many other social, political, and scientific movements influenced the people in their own ways characteristically. Staying in the center of cultural circle with the close association with the various radicals, George Eliot was without exception affected in the crisis of faith and belief.

The most serious challenge religion met in nineteenth century was from the field of biology. Evolution, progress and natural laws were intimately related in understandings of nature. Darwin was a name well known to the whole world. In a letter to Mrs. Bodichon, Eliot expressed her wholehearted admiration for Darwin's theory, "It [the Book] will have a great effect in the scientific world, causing a thorough discussion of a question about which people have hitherto felt timid. So the world gets on step by step toward brave clearness and honesty!" (Spiltters, 1993)

Apart from the social background, Eliot's endeavor in theological and literary translations contributed a lot to her religion of humanity. Through translating a series of philosophic masterpieces such as Strauss's The Life of Jesus, Feuerbach's The Essence of Christianity and Spinoza's Ethics, Eliot probed into the essence of religion and constructed an ideal religious and moral world of her own.

\section{B. Essence of Eliot's Religion of Humanity}

George Eliot was definitely not the first novelist to explore the theme of humanity in the literary world, but she distinguished herself from other Victorian novelists with her special connotations of religion of humanity. In this way, George Eliot promoted a secular moral growth in the whole society.

Virtually, religion of humanity is one of the ways in which Victorians like Eliot came to make up the loss of conventional religious faith. Not all those influenced by the current scientific ideas came to reject the Christian religion, but some felt unable to reconcile their scientific knowledge with the doctrines upheld by the Church. Besides, the questioning of religious orthodoxy at this time involved a moral as well as an intellectual challenge. The strict morality of evangelical households produced a generation of thinkers who felt that the form of religion in which they had been brought up was immoral. The harmonious spiritual world fell apart with the loss of their beliefs and moral conventions.

George Eliot rejected an early evangelical belief on moral and intellectual grounds. Her famous translation of Strauss's Life of Jesus in 1847 gave popular hearing to the theory that Jesus was not divine. When faith was lost, man was placed in an indifferent universe that provided neither a response to his consciousness nor a sanction to his values. The great question for Eliot, as well as for many of her contemporaries, was how man could lead a meaningful and morally satisfying life in an absurd universe. In this case, Eliot began to seek a new religion, a religion that could mediate between man and the alien cosmos. The old religion certainly had this function, but what Eliot sought was a religion that it could do so without escaping into illusion and paralyzing people's soul. Strictly speaking, the religion of the future, Eliot felt, would be a religion highlighting the function of man-religion of humanity. In a letter of 1859 George Eliot wrote, "I have not returned to a dogmatic Christianity - to the acceptance of any set of doctrines as a creed, and a superhuman revelation of the unseen"( Haight, 1965). In A Preface to George Eliot, John Purkis defined religion of humanity as follows:

The religion of humanity was a widely used term in the nineteenth century. On the one hand, it could be used to refer precisely to the new religion invented by Comte, and on the other hand to various post-Christian attempts to salvage the ethical percepts of the old religion while abandoning entirely its supernatural basis. ( Haight, 1965)

The two quotations explicitly indicate George Eliot's views on religion. What George Eliot could not accept in Christianity was only the supernatural or divine part of it. As a result, humanized Christianity could help to heal the split between her rational rejection of the supernatural God and her deepest religious emotion cultivated since her childhood. 
George Eliot is a skeptic of religion but non-atheist. Religion of humanity, for Eliot, is an innovation of traditional doctrines with the transformation of the focus from divinity to secularity, and from God to Man. Compared with Christianity, Eliot's religion of humanity is a kind of life attitude rather than a religion: on one hand, George Eliot discarded the supernatural part in religion and regarded God as a supernatural power without practical meaning; on the other hand, Eliot insistently spread the meaningful ideas in Christianity, which could be found in most of her works, especially the early ones. Notwithstanding her controversial humanist status, Eliot herself showed a great respect for all forms of sincere religious beliefs. In a letter to her friend in 1859, she complained, "I can't tell you how much melancholy it causes me that people are, for the most part, so incapable of comprehending the state of mind which cares for that which is essentially human in all forms of beliefs, and desires to exhibit it under all forms with loving truthfulness. Freethinkers are scarcely wider than the orthodox in this matter" (Pinney, 1963).

Eliot sympathized with those who needed the support of conventional religion, for she saw that all the people demanded a sense of belonging and a way of deserting loneliness and frustration. Eliot felt that the power and value of traditional religion lay in its ability to satisfy these needs. However, Eliot considered that the illusion of God could only paralyze people. She deeply believed that it was more satisfactory if people gained the sense of belonging by trusting themselves instead of visional God. Therefore, the individuality of Eliot's religion of humanity is her dichotomous view on religion and morality, which means she is a skeptic as well as a non-atheist: George Eliot discarded the supernatural and cheating part in Christianity and remained the reasonable beliefs; at the same time, she assimilated the rational parts in Christianity and innovated the religious and moral standards in it.

\section{Silas Marner: The SAVIOR Is NobOdy BUt HuMAN}

Silas Marner was Eliot's masterpiece best exhibiting her religion of humanity. It is said that the novel was created based on her life experience and the hero Marner, was depicted according to Eliot's remote memory of a weaver she had ever seen in her childhood.

Silas Marner was Eliot's most finished work not only because of her mature writing skill but the perfect exhibition of religion of humanity in the story. Religious plot and moral reflections presented in Silas Marner were regarded as Eliot's breakthrough in her theological study as well as the challenge to the traditional beliefs. In the early works such as Scenes of Clerical Life and Adam Bede, Eliot's attitude towards Christianity was half satirical and half positive to its moral standards. Although Eliot sneered at some miscellaneous doctrines and rituals in Christianity, she was never against Christianity openly in her novels. While in Silas Marner, Eliot, for the first time, discussed problems concerning the relation between God and Man, and how could man rescue his degraded soul in case God was not there. Silas Marner was a unique novel that opened up Eliot's religion of humanity to the public in an utter and direct way. In Silas Marner the hero's conversion from orthodox Christianity to a religion of humanity proved that Eliot had made up her mind to break up with her former religion and endeavored to build up a new spiritual world. Through the story of Marner, Eliot boldly brought forth her essence of religion of humanity-only love, instead of God, could save people's soul from hopeless and helpless dark world. The weaver Marner's story was the best demonstration of Eliot's innovated religion.

\section{A. The Loss of Faith}

When Silas Marner first appeared in the story, he was already an old linen-weaver, working day and night in a stone cottage that stood among the nutty hedgerows near the village of Raveloe. In villagers' mind, especially for children, Silas had a half-fearful fascination, because he was rather weird and seldom got touch with anyone in the village except for some necessities. He usually hid himself in that small, dark and morbid cottage which was not far from the deserted stone pit. Eliot depicted Marner more like a devil than a normal man as compared with other villagers. Then Eliot turned her pen towards the history of Marner and told the readers how Marner became a man like this. "His life, before he came to Raveloe, had been filled with the movement, the mental activity, and the close fellowship, which, in that day as in this, marked the life of an artisan early incorporated in a narrow religious sect" (Eliot, 1994). Silas Marner was believed to be a young man of exemplary life and ardent faith, and he was known in Lantern Yard for his devotion to the Dissenting chapel and religion. People believed that even his fainting fits were messages sent from God. So when suspected of theft, he naturally expected that God would clear the crime off him. Ironically, his religious sect tried the case by drawing lots, to let God show who was guilty. This method convicted Marner. Heavy blow not only came from his disappointment at religion, but also from his friend. Knowing that it was his best friend who sold him out, Marner felt desperate down to his heart and "that shaken trust in God and man" (1994).

Silas Marner lost his faith in God and soon left Lantern Yard. Silas felt persecuted by everyone. He thought that if he, an innocent and honest man, was found to be guilty, there must be darkness and injustice in this world. God was always the spiritual consolation for Marner, so he was loyal to God and expected that God would bless him. However, God did not save him but pushed him into the hell. Silas Marner felt that God deceived him. Since then, God was dead in his spiritual world.

\section{B. Desolation in Silas Marner's Spiritual World}

After settling down in Raveloe, Marner lived an obscure life for fifteen years and had as little as possible to do with 
the community. He shut his mind in a narrow world, where he transformed from loving God to loving money. For Marner, gold took place of religion, and he no longer sought spiritual edification from God but from gold coins. He worked sixteen hours each day and hid all his earnings. The only and biggest pleasure for him was counting gold coins like a man marking off days of imprisonment on a wall.

The mechanical work and gold coins constructed the whole life and the support in his spiritual world. However, Silas Marner again lost his faith in life with the robbery of the money. When Marner found all the guineas gone, he "put his trembling hands to his head", and "gave a wild ringing scream, the cry of desolation" (1994). The loss of money meant that Silas's hope vanished and his spiritual world fell apart again. George Eliot's purpose to the plot of robbery was much obvious to readers. For Eliot, the worship of mammon was not the genuine method to save one's soul. Instead, it would degrade man and turn man into devil. Silas's expectation to find joy and support in money was false, and this false hope would sooner or later disappear, just as what happened to Marner.

Then what did George Eliot really want to tell people? What was her suggestion to regain one's belief?

\section{Reconstruction of Faith}

Just as Silas Marner, George Eliot came across the religious crisis in her youth. Fortunately she reconstructed her religious world and brought forth religion of humanity to replace the loss of God. George Eliot put forward her religion of humanity in Silas Marner, and taught people to regain faith by following the example of Silas.

Worship of mammon could not save Marner's soul from helplessness. Only love and sympathy could rekindle hope in life. On a winter night when Silas first found an abandoned infant, he took it for his lost gold, "The heap of gold seemed to glow and get larger beneath his agitated gaze. He leant forward at last, and stretched forth his hand; but instead of the hard coin with the familiar resisting outline, his fingers encountered soft warm curls. It was a sleeping child" (1994). Confused as Silas was, he seemed to see a vision of the old home and the old streets leading to Lantern Yard. The thoughts were very strange to him, "like old friendships impossible to revive; and yet he had a dreamy feeling that this child was somehow a message come to him from that far off life" (1994). The baby stirred Silas's "old quivering of tenderness - old impressions of awe at the presentiment of some Power presiding over his life"(1994). Eliot's words put much emphasis on Silas's remote memory of his peaceful and faithful life in Lantern Yard. Actually, the plot of baby was a symbol, showing that the baby played a key role in Silas's reconstruction of beliefs. The baby took place of gold and light up the flame of hope in Silas Marner's life and saved him from the darkness. "In old days," says Eliot in the story, "there were angels who came and took men by the hand and led them away from the city of destruction. We see no white-winged angels now. But yet men are led away from threatening destruction; a hand is put into theirs, which leads them forth gently towards a calm and bright land, so that they look no more backward, and the hand may be a little child's" (1994). In a sense, it was the baby adopted by Silas and given a name "Eppie", freed Silas's soul from the dark world. Silas Marner got the rebirth and Eppie was the angel to save him from the destruction. Through Eppie, Silas was reconnected to the community because of the village people's commitment to help him raise her rightly. He came to make acquaintances with such kind people in Raveloe as Dolly. Though these people belonged to the Anglican Church, they did not practice any type of dogmatic Christianity but relied on an old-fashioned common sense and a community spirit in their moral decisions. It was love, sympathy and fellow feeling between the people that united them and made them live harmoniously. Eppie also helped Silas reexamine his life. "Eppie called him away from his weaving, and made him think all its pauses a holiday, reawaking his senses with her fresh life, even to the old winter flies that came crawling forth in the earthly spring sunshine, and warming him into joy because she had joy"(1994). Silas was no longer that miser who regarded gold as the only joy in life. Strictly speaking, Eppie made him human again.

From the loss of belief to worship of mammon, then to the regaining of the belief, Silas's story told people that it was neither God nor gold, but a girl, a human being salvaged Silas from his loss of belief. Eppie was the incarnation of human love and sympathy. Later, when Silas Marner and Dolly talked about the robbery in Lantern Yard, they both agreed that there was not only darkness and evil in this world, but also morality and humanity, for Eppie would not have been sent to him if there were not. Symbolically Eppie replaced the stolen gold; psychologically she pulled Silas from his isolation and restored him to human race. Silas's experience told people that nobody but humanity could help people out of their despair. Talking of the distinction between old religion and religion of humanity, Eliot said: "Heaven help us! Said the old religion - the new one, from its very lack of that faith, will teach us all the more to help one another" (Peck, 1992). For George Eliot, nothing could replace love, sympathy and fellow feelings between human beings. When God was not there, only love, the essence of religion of humanity, could rescue people from the absurd universe.

\section{CONCLUSION}

Through the interpretation of Eliot's religion of humanity and tentative demonstration in Silas Marner, it is clear that Eliot's belief put much emphasis on humanity rather than on religion. For Eliot, what people needed to support themselves was not the rigid religious doctrines but the most original feeling in human nature-love. Eliot claimed that the truth in life did not lie in religious belief, but in people's own mind. What rescued Marner from the desolated and destructed world was not God but Eppie, a human being who stood for the mutual feeling among people. The essence of religion was not the blind submission to God, but love, the natural demand for everyone in the world. Therefore, Eliot's 
religion of humanity was more like a life attitude or a life style rather than a definite religious belief. This life attitude told people that they did not have to follow God blindly, but to follow their heart. Only love, sympathy, and fellow feelings among people could make them feel content and meaningful instead of feeling desolated, hopeless and helpless.

Although George Eliot brought forth the new reforms to the conventional religion, one can hardly deny that George Eliot was a religious writer or a didactic writer. Eliot paid more attention to human value, dignity, human nature and feelings, which were almost ignored by Christian doctrines, but Eliot was by no means an atheist. Most virtuous people in her novels were people with religious belief. Eliot did not expect to turn the old religion over. What she hoped to achieve was to desert the superstitious part in Christianity, exalt the valuable moral codes in Christianity, and add her own innovated assertion to the traditional religion. Religion of humanity never tried to replace Christianity, but aimed to spread a new life attitude or a life style. Eliot told readers that religion was not the only way for people to find consolation, and the most direct and effective way to live harmoniously in the real world was to hold love forwards yourself and the people around you.

Although George Eliot's era seems far away from our twenty first century, however, her ideology and spirit reflected from her works hold far more realistic significance for the people stuck in the material-oriented society. While people consume the fruits nurtured by the modernization and industrialization, they fall victim to the bitterness and soreness brought forth. It is hard to deny the fact that a quite number of people live like Marner, the weaver who worshiped mammon with the biggest pleasure in counting money. These people live in a narrow and shallow space constructed in their world, with nothing on their mind but money, fame, and other material stuff. They have forgotten the real meaning of existence in the world, and lose the happiness and significance of being human beings. It is high time that they read Silas Marner to reconstruct their faith and found back the meaning of life.

George Eliot was no doubt one of the most outstanding female writers in Victorian period. Novelist, translator and essayist as she was, George Eliot was more famous for being an extraordinary philosopher as well as a humane thinker. Unlike her contemporary writers who fiercely attacked evil side of society as corruption, hypocrisy, cruelty and immorality from social, political, economic and other perspectives, what Eliot cared about was human nature. Instead of the disappointment and hatred to reality, Eliot had a more realistic and optimistic attitude towards the social problems. Hence, Eliot's works always centered around religion and morality. What Eliot wanted to show in her novels was not evilness but goodness in real life; what she brought to people was love and hope, not hatred and desperation. It is no wonder that F. R. Leavis regarded George Eliot as one of the great British traditions.

However, George Eliot has not received sufficient recognition that she deserved in China. Compared with Jane Austin, Dickens, Thackeray and many other contemporaries, George Eliot and her works were far more familiar to Chinese readers. Study on Eliot's religious beliefs is a worthwhile yet gigantic project. As for this thesis, it is only one of the endeavors to George Eliot study. The thesis defines Eliot's religion of humanity boldly and tentatively interprets Eliot's religious and moral beliefs in Silas Marner, but it is far from satisfactory to give a full and explicit study on George Eliot's ideology and religious and moral values. Fortunately, with more and more attention being paid to this excellent female writer, comprehensive study of Eliot and her religion of humanity will be more and more prosperous, and readers will be lucky enough to get to know George Eliot—one of the most extraordinary female writers in British literature.

\section{REFERENCES}

[1] Adams, Kathleen. (1978). George Eliot and Religion. George Eliot Fellowship Review, 9 (1978): 26-29. Indiana: The Fellowship.

[2] Anthony Trollope. (1923). Autobiography. An Autobiography Ed. Michael Sadleir and Frederick Page. New York: Oxford UP.

[3] Carroll, David R. (1966). Silas Marner: Reversing the Oracles of Religion. Literary Monographs, 1:167-200, 312-14. London: Routledge \& Kegan Paul Ltd.

[4] Eliot, George. (1994). Middlemarch. Hertfordshire: Wordsworth Classics.

[5] Eliot, George. (1994). Silas Marner. London: Penguin Books Ltd.

[6] Hawes, Donald. (2004). Articles on George Eliot in 2002: a Selective survey. ELH, 19.3: 218-27. Maryland: Johns Hopkins University Press.

[7] Haight, G. S. (1965). A Century of George Eliot Criticism. Porton: Houghton Mifflin Company.

[8] Handley, Graham. (1990). State of the Art: George Eliot. Bristol: The Bristol Press.

[9] Leavis, F. R. (1995).The Great Tradition: George Eliot, Henry James, Joseph Conrad. London: Chatto and Windus.

[10] Logan, Peter Melville. (2002). George Eliot and the Fetish of Realism. Studies in the Literary Imagination 35: $27-51$.

[11] Peck, Joan. (1992). ed. Middlemarch. Hampshire: MacMillan Education Ltd.

[12] Pinney, Thomas. (1963). German wit: Heinrich Heine. Essays of George Eliot. London: Routledge and Kegan Paul.

[13] Prentis, Barbara. (1988). The Bronte Sisters and George Eliot: A Unity of Difference. London: The Macmillan Press.

[14] Purkis, John. (1985). A Preface to George Eliot. Harlow: Longman group Limited.

[15] Skilton, David. (1993). ed. The Early and Mid-Victorian Novel. London \& New York: Routledge.

[16] Spiltters, Brain. (1993). George Eliot: Godless Woman. New York: St. Martin's press.

[17] Stephen, Leslie. (1902). George Eliot. London: Macmillan and Co. Ltd.

[18] Stonyk, Margaret. (1983). Macmillan History of Literature: The Nineteenth Century English Literature. London: The Macmillan Press\& Co.Ltd. 


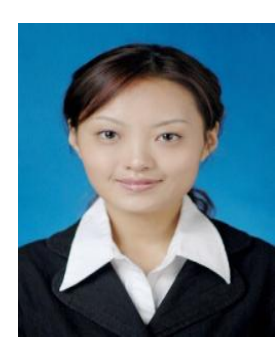

Liang Zhang was born in Henan Province, People's Republic of China in 1981. She finished her MA in English Language and Literature in Wuhan University, China in 2006.

She is currently a professor of Teachers' College of Beijing Union University. She has taught intensive English and advanced English for nearly seven years, and won quite a number of prizes in teaching competitions. She has also supervised a large number of BA dissertations in literature. Her major research interests are TESL and British \& American literature.

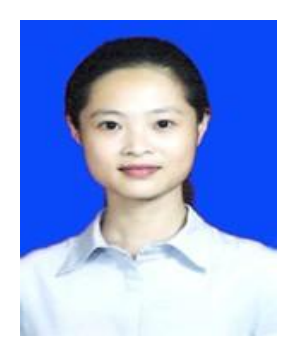

Lingqin Zeng was born in Kaili, Guizhou province, People's Republic of China in 1973. She finished her MA in Guizhou University. She is currently a professor of Teachers' College of Beijing Union University. Her main research field is English and American literature. 